\title{
Maria FrICK*
}

Universidad Pablo de Olavide, España.

mariafrickc@gmail.com

ORCID id: https://orcid.org/0000-0002-0027-3901

Recibido: 30/09/2019 - Aceptado: 20/04/2020

Para citar este artículo / To reference this article / Para citar este artigo

Frick, María. "Carla Witte, una expresionista alemana en Uruguay".

Humanidades: revista de la Universidad de Montevideo, nº 8, (2020): I39- 173.

https://doi.org/| 0.25 | 85/8.6

\section{Carla Witte, una expresionista alemana en Uruguay**}

Resumen: Este trabajo sistematiza la información existente y aporta datos inéditos sobre la vida y la producción de Carla Witte, la artista alemana que vivió en Uruguay entre 1927 y 1943. En el entendido de que fue una de las representantes locales del expresionismo, su biografía es reconstruida para - a partir de allí- abrir nuevas interrogantes sobre la efectiva participación de Uruguay en este movimiento artístico de carácter transnacional.

Palabras claves: Carla Witte, Expresionismo, América Latina, Migración, Redes transatlánticas.

* Docente del Centro Universitario Regional del Este - Sede Treinta y Tres de la Universidad de la República y Candidata a Doctor por la Universidad Pablo de Olavide, España.

** Realizado en el marco del proyecto «Patrimonio cultural y desarrollo local. Una oportunidad singular: la colección Carla Witte del Museo Agustín Araújo» desarrollado conjuntamente por la Intendencia Departamental de Treinta y Tres y la Universidad de la República, a través del Centro Universitario Regional del Este - CURE Treinta y Tres con el financiamiento del Programa Vinculación Universidad- Sociedad y Producción (VUSP - Modalidad 2) de la Comisión Sectorial de Investigación Científica - CSIC. 


\title{
Carla Witte, a German expressionist in Uruguay
}

\begin{abstract}
This article systematizes the existing data and provides new information on the life and production of Carla Witte, the German artist who lived in Uruguay between 1927 and 1943. Understanding she was one of the local representatives of Expressionism, her biography is rebuilt to - from there - open up new questions on the concrete participation of Uruguay in this artistic movement of transnational character.
\end{abstract}

Keywords: Carla Witte, Expressionism, Latin America, Migration, Transatlantic networks.

\section{Carla Witte, uma expressionista alemã no Uruguai}

Resumo: Este trabalho sistematiza as informações existentes e fornece dados inéditos sobre a vida e produção de Carla Witte, artista alemã que viveu no Uruguai entre 1927 e 1943. Sendo uma das principais representantes locais do Expressionismo, se reconstrói a sua biografia para, a partir daí, abrir novas perspetivas sobre a participação efetiva do meio cultural do Uruguai neste movimento artístico transnacional.

Palavras-chave: Carla Witte, Expressionismo, América Latina, Migração, Redes transatlânticas. 


\section{Antecedentes}

Durante las primeras décadas del siglo XX, Sudamérica se convirtió en el hogar de millones de europeos que escapaban de las guerras y la inestabilidad política-económica. Sus países recibieron numerosos artistas que se incorporaron a la escena cultural e influyeron de manera determinante en la posibilidad de producir, para el continente, un arte propio. ${ }^{1}$ Pintores como Lasar Segall y Oscar Goeldi en Brasil, Wolf Bandurek en Paraguay, Wilhelm Wiedemann en Colombia, Juan Rimsa en Bolivia, Adolfo Winternitz en Perú o Hans Michael en Ecuador, actuaron como eslabones de una compleja red transnacional que facilitó la apropiación y reelaboración de las ideas y elementos plásticos expresionistas, en la creación de un arte nuevo y singular. ${ }^{2}$

En Uruguay, sin embargo, todavía existen muy pocos datos sobre algunos de estos artistas inmigrantes, entre los que puede contarse a József Cziffery, Hans Platscheck y Luisa Richter, por nombrar solo algunos. Y poco se conoce hasta el momento de Carla Witte, la pintora alemana que vivió en Montevideo desde 1927 hasta su muerte, en 1943. A pesar de que Mariví Ugolino $^{3}$ ha logrado mantener viva su memoria, esta artista ha permanecido prácticamente olvidada, sepultada en una tumba sin nombre, con gran parte de su producción en manos privadas o en museos públicos sin un análisis sistemático de su aporte al arte local.

En un momento en el que la historia del arte ha comenzado a incluir identidades que cuestionan los discursos tradicionales, este artículo apunta a revertir tal ausencia de conocimiento, sistematizando la información existente y aportando datos que permitan reconstruir la biografía y producción plástica de esta artista. Realizado en el marco del proyecto de investigación «Patrimonio cultural y desarrollo local. Una Oportunidad singular: la colección Carla Witte del Museo Agustín Araújo» de la Universidad de la República, este trabajo presenta las características generales de la vida y obra de esta artista, identificando algunos aspectos clave de su aporte en el marco del contexto artístico en el que fue producida. El texto no se propone, en este sentido, defender una tesis o arribar a reflexiones concluyentes, sino exponer los

1 María Frick, «El expresionismo en la pintura latinoamericana: transferencias y trascendencia», Atrio, $\mathrm{n}^{\circ} 20$ (2014): 132.

2 María Frick, "Los salvajes del Sur: inmigración y expresionismo en Uruguay en la primera mitad del siglo XX", MODOS 4, n 1 (2020): 181.

3 Se agradece muy especialmente el apoyo de Mariví Ugolino en la elaboración de este artículo. 
principales avances realizados en la articulación de un relato que todavía está en construcción. ${ }^{4}$

\section{El camino inverso}

El abordaje de la obra de Carla Witte se enmarca en la preocupación general que existe en la región por intentar desarmar las narraciones establecidas, proponiendo genealogías que mapean y reconstruyen las historias que nunca fueron totalmente construidas o que permanecen opacas u ocultas en las narrativas convencionales. ${ }^{5}$ Se alinea, además, con las observaciones de algunos actores locales sobre el desconocimiento, por parte de la crítica y la academia, de formas artísticas marginales respecto a la corriente principal. ${ }^{6}$

En lo que se considera un «giro historiográfico», estos nuevos enfoques asumen el carácter multidireccional y sincrónico de las relaciones entre las metrópolis europeas y latinoamericanas, entendiendo las obras de arte como producto de la «combinación de coincidencias y relaciones físicas, además de redes virtuales o redes de influencia ejercidas a través de publicaciones, debates, cartas, revistas y tantos otros mecanismos que contribuyen al entramado de influencias y debates» que superan los límites de lo nacional. ${ }^{7}$

De esta manera, se replantea la hipótesis tradicional acerca de las influencias europeas unidireccionales hacia Latinoamérica, para «seguir los itinerarios [...] de Norte a Sur y viceversa y analizar de qué manera ambas escenas se enriquecieron mutuamente o retroalimentaron convicciones preexistentes». ${ }^{8}$ Y es por ello que se vuelven especialmente importantes los vínculos creados a través de los viajes, estancias y migraciones de artistas, que permitieron

4 En este punto debe enfatizarse la debilidad de las fuentes locales (archivos, bibliotecas, registros) para la reconstrucción de la biografía de Carla Witte y de los miembros de su entorno, así como la dificultad de conseguir la información necesaria de las fuentes europeas (archivos, bibliotecas, registros) debido a que muchos documentos de la época fueron destruidos durante las guerras. En su caso, además, no existe un archivo personal que pueda ser analizado con pertinencia y profundidad, sino que todos los datos que se mencionan han sido obtenidos en el marco de esta investigación. Tampoco se ha publicado, por el momento, el catálogo razonado de sus obras, que se presentará públicamente durante el año 2020.

5 Andrea Giunta y George F. Flaherty, "Latin American Art History: An Historiographic Turn”, Art in Translation $1, \mathrm{n}^{\circ} 9$ (2017): 126.

6 Pablo Thiago Rocca, Catálogo de la exposición “Arte Naîf en Uruguay” (2015): 15.

7 Gabriel Pérez Barreiro, «El diálogo transatlántico en la Abstracción Geométrica», Catálogo de la exposición "América fría: la Abstracción Geométrica en Latinoamérica (1934-1973)" (11 de febrero - 15 de mayo de 2011).

8 Isabel Plante, Argentinos de París. Arte y viajes culturales durante los años sesenta (Buenos Aires: Dehesa, 2013$), 59$. 
la importación de patrones europeos y su combinación y procesamiento en los campos culturales de la región, activos y receptivos a las influencias extranjeras. ${ }^{9}$

En Uruguay, en particular, los primeros en establecer un contacto sistemático y generacional con la pintura europea fueron los pintores nacidos entre 1880 y 1890, quienes, beneficiados por la Ley de Becas de 1907 o a su propio costo, realizaron viajes y estancias de formación y a su regreso al país contribuyeron de manera decisiva a la renovación del ambiente artístico local. ${ }^{10}$ Este es el caso, por ejemplo, de Carlos Alberto Castellanos, José Cuneo, Adolfo Pastor, Norberto Berdía, Manuel Rosé y Ricardo Aguerre, en cuyas obras se observan e identifican gravitaciones expresionistas.

Sin embargo, los inmigrantes también desempeñaron un papel central en la evolución del arte nacional, al desarrollar en el país las tendencias latentes en sus contextos culturales anteriores. ${ }^{11}$ Es justamente por ello que, tal como sugiere Verónica Panella, es necesario superar el relato tradicional sobre el periplo migratorio como «una suerte de camino lineal donde los artistas, generalmente jóvenes, generalmente hombres, buscan en el Viejo Continente la apertura estética y mental que no encuentran en las anquilosadas aldeas que los vieron nacer» para comenzar a incorporar el «análisis de casos (minoritarios en número, sin duda, de profundas consecuencias para el país de recepción, pero ineludibles también para la trayectoria del artista en cuestión) de creadores europeos que hacen el viaje, personal y artístico, inverso». ${ }^{12}$

Sin lugar a dudas, este es el caso de Carla Witte, quien integra esa «gran constelación de mujeres» que, a pesar de haber tenido visibilidad y reconocimiento en su época, no ingresó de manera definitiva en la memoria artística nacional. ${ }^{13}$ Además de ser mujer y migrante, ella optó por participar en un movimiento cuya postura crítica desafió el carácter uniformizante y equilibrado del paradigma cultural hegemónico, a través de un discurso

9 Sandra De la Fuente y Diana Wechsler, «La Teoría de la Vanguardia: del centro a la periferia» V, Jornadas de Teoría e Historia de las Artes (1993), 52.

10 Gabriel Peluffo, Historia de la Pintura Uruguaya - Tomo 2: Representaciones de la modernidad (1930-1960) (Montevideo: Banda Oriental, 1999), 69.

11 María Frick, «Los salvajes del Sur: inmigración y expresionismo en Uruguay en la primera mitad del siglo XX», MODOS 4, $\mathrm{n}^{\circ} 1$ (2020): 184.

12 Verónica Panella, «Mujeres artistas en las vanguardias pictóricas latinoamericanas de la primera mitad del siglo XX: una imperfecta antología», La pupila: los primeros seis años (207-2013), comps. Oscar Larroca, Oscar y Gerardo Mantero (Montevideo: Artes Gráficas, 2013), 406.

13 Verónica Panella, «En construcción: la difícil inclusión de las artistas mujeres en la Historia del Arte», La Pupila, n 17 (2011): 24. 
crítico que desmitificaba lo culto y decorativo. Es por ello que su trayectoria es especialmente significativa tanto en términos del análisis y abordaje de su propia obra como del planteamiento de nuevos interrogantes sobre las trayectorias y formas artísticas marginales respecto a las narraciones establecidas sobre el arte nacional. Si bien Uruguay no se ve a sí mismo como un socio activo del movimiento expresionista internacional, Carla Witte es un testimonio de que el expresionismo colaboró de alguna manera con el desarrollo de la corriente de arte figurativo, que en la década del treinta buscaba diversas aproximaciones a la temática social y popular ${ }^{14}$.

\section{La estudiante alemana}

Carla Witte nació el 20 de mayo de 1889 en la ciudad de Leipzig, Alemania, en el hogar evangélico-luterano formado por el comerciante Carl Witte, su esposa, Jenny Espenhagen, y sus tres hijos: Carla Elizabeth, Horst Friedrich (1891) y Asta Henriete (1892). ${ }^{15}$ A pesar de que los Witte eran humildes, ${ }^{16}$ Leipzig era entonces una ciudad pujante y un importante centro comercial y cultural de Europa central.

Entre 1905 y 1908, Carla Witte estudió en la Königliche Akademie für graphische Künste und Buchgewerbe (Real Academia de Artes Gráficas y Técnica del Libro) de Leipzig, hoy conocida como Hochschule für Graphik und Buchkunst (Colegio de Artes Gráficas del Libro). Dirigida por Max Seliger, esta institución era la más prestigiosa del país en técnicas modernas de diseño y producción de libros y la primera de su tipo en aceptar mujeres en su estudiantado. De hecho, Carla Witte formó parte de la primera generación de alumnas mujeres, siendo — según las palabras del mismo director— «una prometedora candidata

14 Gabriel Peluffo, Realismo social en el arte uruguayo, 1930 - 1950 (Montevideo: Museo Juan Manuel Blanes, 1992), 21.

15 Los datos que refieren a la conformación de la familia provienen en su totalidad de las partidas de nacimiento y defunción. Asta Henriete murió en 1955 soltera y sin hijos, mientras que se desconoce el lugar y fecha de fallecimiento de Horst Friedrich, quien habría abandonado el país en 1911. Según los datos relevados por Mariví Ugolino, él pudo haber emigrado a Nueva York, Estados Unidos.

16 A pesar de que no se conocen detalles sobre la vida de la familia Witte en Alemania, Jenny Espenhagen describía a su hija como «una pintora talentosa, pero de condición muy humilde» (carta enviada por la Sra. Espenhagen al Sr. Seliger, con fecha 30 de mayo de 1917). 
de una clase magistral» a quien «hubiera sido fácil, con su talento, obtener encargos o un trabajo acorde a su formación artística». ${ }^{17}$

A pesar de que abandonó sus estudios, puede suponerse que Carla Witte participó activamente del ambiente cultural de la ciudad, que se había convertido en un lugar de referencia para la impresión de libros y artes gráficas que congregaba a muy reconocidos artistas e ilustradores. ${ }^{18}$ Durante esos años, además, se estaba forjando en Alemania la especificidad del diseño gráfico comercial como tal, nucleando oficios que hasta ese momento habían sido independientes, ${ }^{19}$ por lo que es probable que Leipzig estuviera impregnada de un fuerte vanguardismo, visible a través de los pósters públicos y las imágenes de marcas, así como de los portfolios de los propios artistas.

El único trabajo que se conoce de Carla Witte de sus años de estudiante es un calendario [Imagen 1] de características modernistas inspiradas en el movimiento Jugendstil, de gran influencia en las artes gráficas desde fines del siglo XIX hasta la Primera Guerra Mundial. Esta pieza se distingue por incorporar como figura central lo que parece ser un indígena sudamericano vistiendo poncho similar a los Makuñ típicos del pueblo mapuche o araucano que habita en Chile y Argentina.

17 Datos obtenidos de su legajo de estudiante en dicha institución, los que fueron solicitados expresamente para esta investigación. En el mismo consta que Carla Witte llegó a finalizar el sexto semestre y que luego intentó retomar los estudios, solicitando sin éxito una beca a través de la mediación de su madre.

18 En 1914, por ejemplo, Leipzig albergó la primera Internationale Buchund Grafik. Ausstellung-BUGRA (Exposición Internacional de Libros y Gráficos), en la que participaron 23 países y 2 millones de visitantes, además de artistas de la talla de Edvard Munch, Käthe Kollwitz y Gustav Klimt.

19 Kathleen Chapman, Expressionism and poster design in Germany 1905-1922: between spirit and commerce (Leiden, Boston: Brill, 2019), 11. 


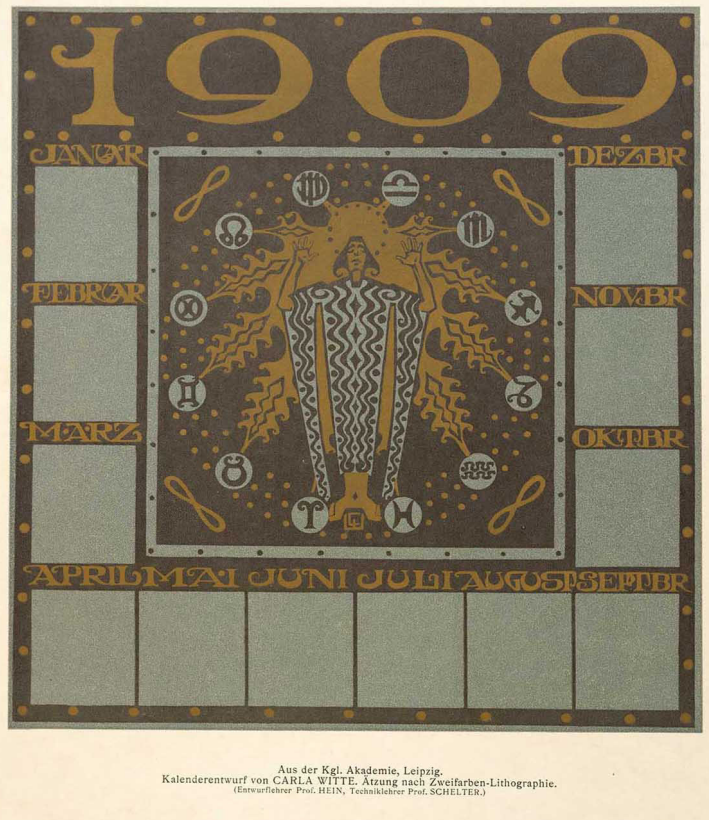

Imagen I: Carla Witte (Diseño de calendario, 1909) Litografía, $20 \times 18,5 \mathrm{~cm}$. Archivo de la autora. Fotografía: Micaela Fernández.

En general, el modernismo tendía a incorporar motivos provenientes de otras culturas o el arte popular, práctica que continuó luego el expresionismo a partir del arte y objetos de las tradiciones campesinas europeas o las sociedades tribales de África y el Pacífico Sur. Pintores como Emil Nolde también se inspiraron en formas y objetos de las culturas amerindias, como es el caso de la inclusión de una cabeza encogida de un indio yoruna del pueblo Mundurucu (Brasil) en «Naturaleza muerta con máscaras III». Sin embargo, llama especialmente la atención la centralidad visual de este poncho que utiliza el diseño del guemil, un símbolo de la de la iconografía mapuche en forma de cruz que representa el arte de la manufactura, la ciencia y el conocimiento. En la obra de Witte, este patrón ha sido suavizado con líneas más curvas y en movimiento que mantienen las tonalidades propias del tejido natural y se adaptan con la propuesta gráfica y la búsqueda modernista de una obra de arte total. 
En 1908, Carla Witte se mudó junto con su familia a Berlín, donde residió al menos hasta el 13 de octubre de $1923,{ }^{20}$ cuando partió, vía Bremen, hacia Buenos Aires con destino final Asunción del Paraguay. ${ }^{21}$ Este hecho es relevante si se considera que Berlín era entonces la sede de muchos de los principales museos, galerías y coleccionistas de Alemania. La ciudad había desplazado a Múnich como eje del desarrollo expresionista, reuniendo a los miembros de Die Brücke (El Puente) y de Blaue Reiter (Jinete azul), además de otros artistas que se asociarían eventualmente con el movimiento, como Oskar Kokoschka, los escultores Wilhelm Lehmbruck y Ernst Barlach ${ }^{22}$ y los pintores Ludwig Meidner, Lyonel Feininger y Conrad Felixmüller. Lugares como el Café des Westens (Café del Oeste), publicaciones como Der Sturm (La tormenta) o Die Aktion (La acción), y galerías como las de Paul y Bruno Casirer, Alfred Flechteim, Jsarel Ber Numen, Fritz Gurlitt y Helmut Walden, funcionaban además como importantes centros de reunión que permitían que las distintas cepas del expresionismo tuvieran la oportunidad de mezclarse y retroalimentarse, fortaleciendo y ampliando enormemente el alcance del movimiento.

Durante esos años, Carla Witte llegó a tomar un curso de gráfica y arte del libro con Emil Orlik, en la escuela del Königlichen Kunstgewermuseums (Museo real de Artes Decorativas). ${ }^{23} \mathrm{Y}$ a pesar de que no hay otros registros o información adicional sobre su producción en Europa, algunas de las obras del acervo del Museo Agustín Araújo muestran tanto su formación como su gran manejo técnico y destreza artística. En particular, trabajos como «Naturaleza muerta (Frutas y tucán de madera)» [Imagen 2], «Retrato (Mujer guaranî)» ${ }^{24}$, «Retrato

20 Según los datos aportados por Mariví Ugolino, la familia se habría mudado por motivos laborales vinculados al Sr. Witte. Sin embargo, durante ese período Carla Witte tuvo también residencias breves en las ciudades de Osnabrück (1915) y Flensburg (1917), en el norte de Alemania.

21 Información disponible en las «Listas de pasajeros de Bremen» provistas por la Cámara de Comercio de Bremen y los Archivos del Estado de Bremen: http://www.passengerlists.de. La misma base de datos provee información sobre otros pasajeros de apellido Witte que emigraron a América del Sur (Montevideo, Buenos Aires, Río de Janeiro y Santa Catarina) entre 1925 y 1931, aunque no se encontró información genealógica que permita comprobar vínculos de parentesco. Por otro lado, es posible que ella también haya visitado España y Brasil, como lo sugieren sus obras «Pueblo de Montserrat», «Puente de Toledo» $\mathrm{y}$ «"Laguna - Rio de Janeiro».

22 Investigaciones anteriores han mencionado que Carla Witte llegó a colaborar con Ernst Barlach durante su vida en Alemania. No obstante, según lo informado por el Dr. Karsten Müller, Director de la Casa Ernst Barlach / Fundación Germann F. Reemtsma (Hamburgo), el día 12 de agosto de 2019, no existe información sobre ningún tipo de vínculo entre Carla Witte y Ernst Barlach.

23 De acuerdo con los datos relevados por Ugolino, Carla Witte asistió un trimestre a la Fachklasse für Graphik und Buchkunst (Clase especializada de gráfica y arte del libro), a pesar de que luego no continuó sus estudios en dicha institución.

24 Carla Witte, «Retrato (Mujer guaranî)», s/f, óleo sobre tela, 43 x 61 cm. Museo Agustín Araújo, Treinta y Tres ( ${ }^{\circ}$ de inventario: 564$)$. 
(Rostro de hombre de frente) $»^{25}$, «Retrato (Mujer angustiada)» ${ }^{26}$, «Retrato (Rostro de mujer de frente) ${ }^{27} \mathrm{o}$ «Estudio (desnudo femenino) ${ }^{28}$ evidencian su formación y versatilidad plástica, que caracterizaran sus distintas etapas como artista.

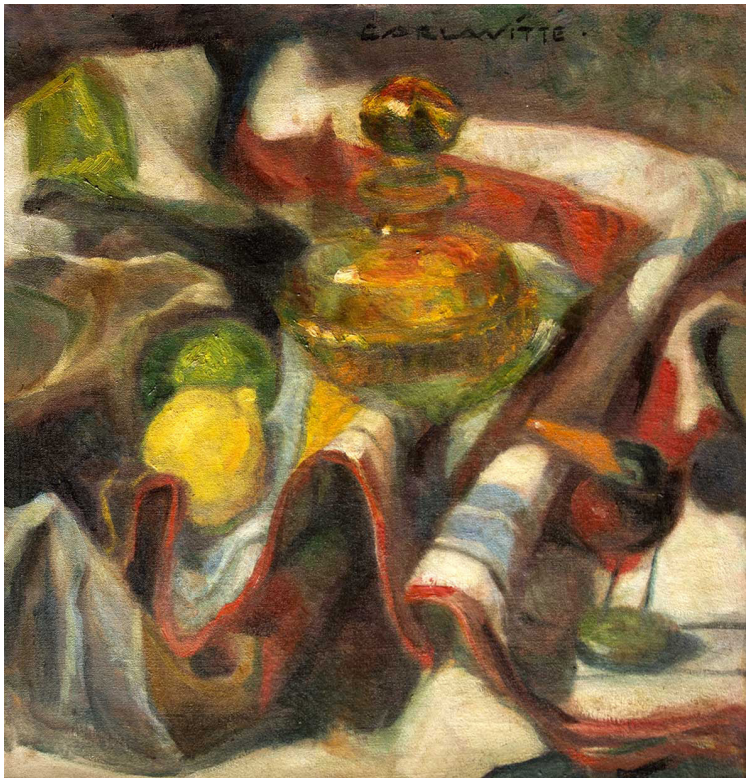

Imagen 2: Carla Witte «Naturaleza muerta (Frutas y tucán de madera)", s/f. Óleo sobre tela, $35 \times 37 \mathrm{~cm}$. Museo Agustín Araújo, Treinta y Tres ( $\mathrm{N}^{\circ}$ de inventario: 593$)$. Fotografía: Ariel Mermalejo.

25 Carla Witte, «Retrato (Rostro de hombre de frente)», s/f, pastel, 31 x 36 cm. Museo Agustín Araújo, Treinta y Tres $\left(\mathrm{N}^{\circ}\right.$ de inventario: 120$)$.

26 Carla Witte, «Retrato (Mujer angustiada)», s/f, carbonilla, 21 x 28 cm. Museo Agustín Araújo, Treinta y Tres $\left(\mathrm{N}^{\circ}\right.$ de inventario: 487).

27 Carla Witte, «Retrato (Rostro de mujer de frente)», s/f, tinta, 12 x $17 \mathrm{~cm}$. Museo Agustín Araújo, Treinta y Tres ( $\mathrm{N}^{\circ}$ de inventario: 525$)$.

28 Carla Witte, «Estudio (Desnudo femenino)», s/f, lápiz, sin medidas. Museo Agustín Araújo, Treinta y Tres $\left(\mathrm{N}^{\circ}\right.$ de inventario: 862). 


\section{La migración a Paraguay}

Cuando viajó a Asunción, Carla Witte tenía 34 años, era soltera, declaraba ser «pintora y escultora» y provenir del Estado de Brandemburgo. Si bien no se conocen los motivos por los que ella decidió emigrar, algunos hechos ayudan a imaginar por que pudo haber elegido este destino, que para muchos artistas era una especie de «Oriente latinoamericano». ${ }^{29}$

Tras finalizar la Gran Guerra, los primeros años de la República de Weimar eran particularmente difíciles en Alemania debido a la crisis económica y las luchas políticas por la configuración de la nueva República. Entre 1918 y 1923, tuvo lugar la ocupación por Francia de la cuenca del Ruhr, el intento de golpe de Hitler en Múnich y una inflación tan alta, que un pan llegó a costar veinte mil millones de marcos. Es muy probable entonces que Carla Witte estuviera sumida en una situación desesperante que la llevara, al igual que a muchos compatriotas, a buscar nuevos horizontes en las propuestas que realizaban las distintas Kolonisationsgesellschaften (sociedades o empresas de colonización)..$^{30}$ Tal como fue descrito por su madre: «La lucha por el pan de cada día, naturalmente no le permitió volcar todo su talento, y eso la hace muy infeliz. Así seguirán transcurriendo sus mejores años de vida hasta que un día, cansada de tanto trabajar, se dará cuenta de que en su corazón ya no quedan imágenes artísticas». ${ }^{31}$

En esos años, además, Paraguay realizaba campañas publicitarias en periódicos y revistas alemanas ofreciendo numerosas facilidades para aquellos colonos dispuestos a ocupar su territorio nacional, escasamente poblado. ${ }^{32}$ Entre las facilidades se encontraban, el financiamiento del tramo en barco desde Buenos Aires hasta Asunción, el hospedaje y la comida durante los primeros días, las importaciones libres de impuestos para artículos para el hogar e implementos, el asesoramiento legal y el acceso a tierras cultivables, la obtención de derechos civiles y de la ciudadanía, y —a diferencia de

29 Raquel Pereda, Carlos Alberto Castellanos, Imaginación y realidad (Montevideo, Edición Fundación Banco de Boston, 1997), 46.

30 Marisa Micolis, Une communaute allemande en Argentine: El Dorado: problemes dé intégration socio-culturelle (Québec: Centre International de Recherches sur le bilinguisme, 1973).

31 Carta procedente del legajo de estudiante de Carla Witteen la Königliche Akademie für Graphische Künsteund Buchgewerbe (Real Academia de Artes Gráficas y Comercio de Libros) de Leipzig en la que su madre solicita sin éxito una beca de estudios que le permita a Carla completar su formación académica.

32 Margot Peroutka, «Die Deutsche Einwanderung nach Paraguay: Vom späten 19. Jahrhundert bis ins frühe» 20." (Inmigración alemana a Paraguay desde finales del siglo XIX hasta principios del siglo XX) (Tesis de maestría, Universität Wien, 2012), 22. 
muchos otros países - la posibilidad de preservar las huellas culturales o "germanismo. . ${ }^{33}$ Es entendible entonces que Carla Witte viera en Paraguay la esperanza de un nuevo comienzo.

A pesar de ello, el único testimonio que existe por el momento del paso de Carla Witte por Paraguay surge de sus propias obras, ${ }^{34}$ entre las que se destaca una serie de témperas entre las que se encuentran: «Sin título (Selva)», ${ }^{35}$ «Sin título (Caraguatá)» ${ }^{36}$ y «Sin título (Carro tirado por bueyes)» [Imagen 3]. Estas obras presentan la emoción y la expresión características de la pintura de tendencia postimpresionista, tanto en términos del color y la pincelada, como en la visión subjetiva del mundo.

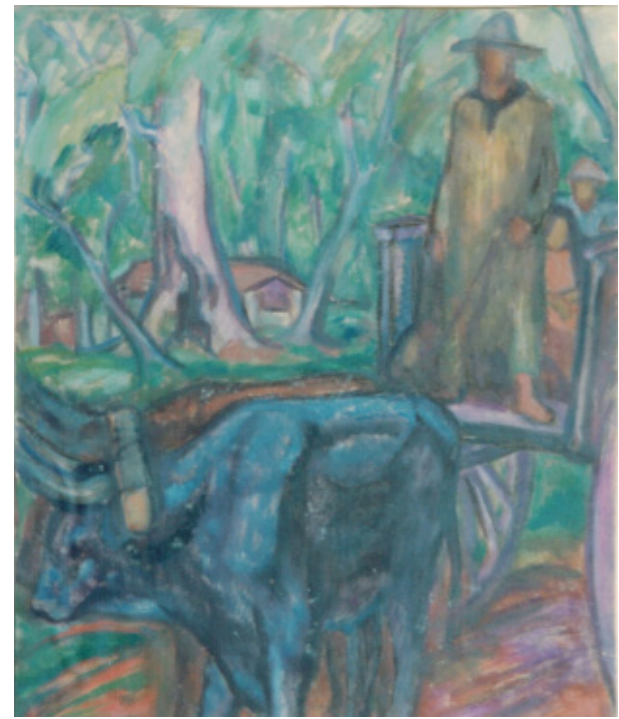

Imagen 3: Carla Witte, Sin título -Carro tirado por bueyes, $\mathrm{s} / \mathrm{f}$. Témpera, 34,5 x $43 \mathrm{~cm}$. Museo Agustín Araújo, Treinta y Tres ( $\mathrm{N}^{\circ}$ de Inventario: 548$)$.

Fotografía: Sandra Marroig.

33 Thomas Adam, Germany and the Americas: culture, politics and history. A multidisciplinary encyclopedia. Vol. I (California: ABC Clio, California, 2005), 30.

34 De acuerdo con la consulta N¹92 del 15/07/2019 realizada a la Oficina de Servicio de Atención al Ciudadano de la Dirección de Gabinete de la Dirección General de Migraciones de Paraguay, no existe información disponible sobre la entrada o estancia de Carla Witte en Paraguay entre los años 1923 y 1932. Anterior a la creación de la Dirección General de Migraciones en el año 1974, no se llevaban registros de los ciudadanos extranjeros que residían en el país, y tampoco se encontraron registros de ninguna persona con esos datos en los sistemas informáticos. No obstante, la información que se adjunta en el legajo de ciudadanía uruguaya de Carla Witte, con fecha de 7 de julio de 1932, se desprende que ella viajó nuevamente a ese país el día 5 de junio de 1931.

35 Carla Witte, «Sin título (Selva)», s/f, témpera, 34 x $41 \mathrm{~cm}$. Museo Agustín Araújo, Treinta y Tres $\left(\mathrm{N}^{\circ}\right.$ de inventario: 549).

36 Carla Witte, «Sin título (Caraguatá)», s/f, témpera, 34 x 41 cm. Museo Agustín Araújo, Treinta y Tres $\left(N^{\circ}\right.$ de inventario: 550). 
Esta serie también representa la aparente simplicidad de la nueva cultura extranjera. En ella es posible sentir el peso abrumador de la naturaleza en el paisaje (inmensos follajes, enormes árboles, y vegetación que tapa el horizonte) y la perspectiva (ya sea mediante el encuadre como por los motivos escogidos) de la vida cotidiana en el nuevo lugar: carros tirados por bueyes, mujeres con cestas en las cabezas, mercados en torno a las iglesias, el ganado que pasta en campo abierto, la belleza de las indígenas y la pequeñez del hombre en la selva. En este sentido, se caracterizan por un abordaje similar al que tuvieron otros pintores extranjeros que arribaron a la región, como es el caso de las selvas brasileras de Lasar Segall, los campesinos de Hans Michaelson o las fiestas populares andinas de Juan Rimsa.

En general, a pesar de tener un fuerte componente social o humano, estas obras no se enmarcan necesariamente en una búsqueda identitaria en el marco de los distintos procesos históricos de emergencia y afianzamiento de la nación moderna si no que representan, en cierta medida, el efecto liberador de las nuevas culturas «primitivas» frente a las expectativas, normas y decadencia de la sociedad europea. ${ }^{37}$ En el expresionismo europeo, además, el paisaje continuaba la tradición romántica que consideraba la naturaleza como el consuelo de una vida más simple y un antídoto contra la corrupción de la vida moderna y las rígidas normas sociales de la burguesía.

En «Sin título (Carro tirado por bueyes)», en particular, se constata la fuerte presencia del primer plano, que luego se desdibuja en manchas de color, pinceladas yuxtapuestas y líneas que dan forma al paisaje. En este caso, el peso de la composición está en el primer buey en tonos de azul y fuertes líneas de contorno, que sobresale de los límites de la propia obra. En el segundo plano, el cochero y sus acompañantes toman forma a partir de bloques de color de escasos límites y definición, mientras que, en el tercer plano, unas pocas líneas definen los contornos de una casa y algunos árboles que sostienen las manchas y pinceladas verdes que sugieren el resto del paisaje. Estos elementos son suficientes, de todas maneras, para transmitir el clima (momento del día, temperatura y hasta olor) del lugar.

No obstante, de esta etapa de Carla Witte también existen registros de una fuerte tendencia expresionista, no solo en términos de la temática sino del tipo de elementos plásticos utilizados. Este es el caso, por ejemplo, de «El loco de Caacupé» [Imagen 4], que representa de manera descarnada la 
mirada penetrante, esquiva y peligrosa de un personaje de dicha localidad. $\mathrm{Al}$ igual que obras como «El manicomio (el loco)» de Erich Heckel, «Cabeza papúa» de Emil Nolde o «La boba» de Anita Malfatti, este trabajo se enmarca en la tendencia general de los artistas expresionistas de representar seres y conductas que viven fuera de los límites convencionales de la sociedad burguesa. En él, la importancia del trazo y el peso de la composición sobre la izquierda indican la posibilidad de una escena fuera del cuadro que - por un breve momento- atemoriza, al mismo tiempo que deja ver una actitud plástica que se volvería más fuerte en los años siguientes.

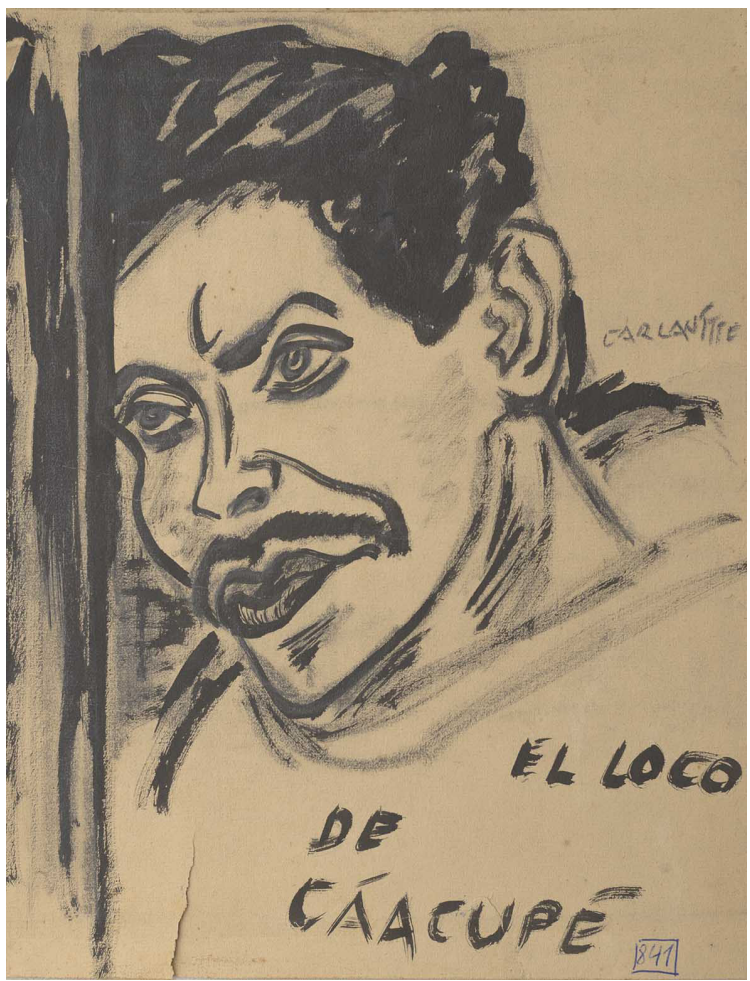

Imagen 4: CarlaWitte, El loco de Caacupé, s/f. Tinta, 22 × $26 \mathrm{~cm}$. Museo Agustín Araújo, Treinta y Tres ( $\mathrm{N}^{\circ}$ de Inventario: $\left.34 \mathrm{I}\right)$. Fotografía: Micaela Fernández. 


\section{El desembarco en Montevideo}

Carla Witte arribó a Uruguay el 26 de julio 1927, cuatro años después de viajar a Paraguay, como pasajera de tercera clase del vapor "Württemberg" procedente de Hamburgo. En este caso también se desconocen las razones que la trajeron a este destino, aunque es posible pensar que ella pudo haberlo elegido a través de familiares o amigos ya radicados en el país, ya que la mayoría de los inmigrantes que arribaron en ese tiempo venía guiada por relaciones personales que les servían para conseguir información e insertarse en el mercado de trabajo. ${ }^{38}$

En esos años, además, Uruguay vivía una época de prosperidad que lo mantenía en gran medida distante de los avatares del mundo. Con el modelo político impulsado desde 1903 por José Batlle y Ordóñez y sus predecesores, el país disfrutaba de avanzadas reformas sociales, una democracia estable y una ascendente clase media. Un largo período de obras públicas había resultado en la construcción de escuelas, asilos, hospitales y grandes edificios emblemáticos. Las redes de alcantarillado, las líneas de corriente eléctrica y los tranvías se habían expandido, el puerto crecía con nuevas dársenas y escolleras, y las carreteras y puentes comunicaban al país entero. Tal como describe Carlos Quijano, Uruguay parecía entonces un lugar donde parecía posible refugiarse:

Un mundo de democracia política, de paz interna, un mundo además, en el que parecía haberse detenido la rueda de la historia, un mundo arcádico que tenía horror de la sangre y la aventura, dominado y regido por ideas que habían hecho sus pruebas. Entre el 10 y el 30, Uruguay fue un remanso, al cual llegaban desvaídos los truenos que anunciaban nuevas y fecundas tormentas. La guerra del 14-18 nos dio una desconocida riqueza. Las crisis que a partir del 21 empezaron a producirse en cadena, nos fue imposible comprenderlas. La revolución del 17, la caída de la libra esterlina el desplazamiento del eje financiero del mundo fueron otros tantos fenómenos que escapaban a nuestros cartabones y cánones. Eran excrecencias o excepciones que aseguraban la permanencia de la regla o que para los menos agudos, puesto que contrariaban el dogma y la fe, no existían. ${ }^{39}$

38 Silvia Facal Santiago, «Recorriendo el largo camino de la integración: los judíos alemanes en Uruguay», Amérique Latine Histoire et Mémoire. Les Cabiers ALHIM (2006).

39 Carlos Quijano, "Dardo Regules", Marcha (9 de julio de 1948). 
Witte tomó contacto rápidamente con la colonia de habla alemana, ya que para la Navidad de ese mismo año le obsequió una de sus obras al abogado Max Guyer, quien sería luego su albacea ${ }^{40}$ Hay evidencia de que ella tuvo contacto con la comunidad de la Hindenburgschule (actual Colegio Alemán) ${ }^{41}$ y existen testimonios ${ }^{42}$ de que participó en la Congregación Evangélica Alemana de Montevideo, en cuya iglesia —ubicada en la calle Juan Manuel Blanes 1116 - se conserva una de sus esculturas ${ }^{43}$. Y existen datos que prueban su vínculo con la familia del médico alemán Carl Brendel, ${ }^{44}$ de quien llegó a heredar tres terrenos en la antigua Colonia Gervasio en el Departamento de Rocha ${ }^{45}$ un asentamiento germánico ${ }^{46}$ que nunca llegó a prosperar. ${ }^{47}$

Witte también se volvió amiga cercana de la bailarina alemana Ingeborg Bayerthal (conocida como Inx o Inge), quien llegó a Uruguay junto con su marido, el crítico de arte también alemán Fritz Leo Bayerthal (cuyo seudónimo era Friedrich Bayl).$^{48}$ Los Bayerthal tenían una presencia muy activa en el circuito cultural local, ya que Ingeborg fundó la compañía de danza moderna «Grupo Bayerthal de Montevideo» y Friedrich abrió «Arte Bella», la primera galería de arte contemporáneo de la ciudad, ${ }^{49}$ y solían realizar reuniones en las que participaban artistas locales como Oscar García Reino, Vicente Martín, Miguel A. Pareja y el alemán Hans Platschek. Este vínculo quedó plasmado en la estatuilla que Witte le dedicó a su amiga [Imagen 5] $]^{50}$, un delicado torso

40 El vínculo surge de los documentos relativos a la herencia de Carla Witte, facilitados amablemente por el historiador rochense Félix Flügel. La obra que se menciona, desconocida hasta la realización de esta investigación, es propiedad particular de la familia González Guyer.

41 Información provista por Mariví Ugolino, a partir de la inclusión de obras de Carla Witte en la lista de premios de un festival escolar de dicha institución.

42 Testimonio de Enrique Brandner, a través de Ricardo Hein, en comunicación con la autora vía correo electrónico (noviembre de 2018).

43 Carla Witte, Sin título (Manos orando), s/f, madera. Congregación Evangélica Alemana de Montevideo (iglesia de la calle Juan Manuel Blanes 1116).

44 Si bien el Dr. Brendel residió en Uruguay entre 1867 y 1892, algunos de sus hijos retornaron luego al país. Según la noticia publicada en el ejemplar número 12 de la revista "La Pluma” (Año 3, v. 12, jun. 1929, p.49), donde se comenta la exposición realizada por alumnas de Carla Witte en el Salón de la «Casa Moretti, Catelli y Cia» durante el mes de mayo de 1929, Carla Witte daba clases de pintura a Olga Brendel de Rust.

45 Félix Flügel, «La Colonia Agrícola de Santa Teresa: una experiencia migratoria fracasada», Revista Histórica Rochense, $\mathrm{n}^{\circ} 2$ (2013).

46 Fernando Mañé Garzón y Ángel Ayestarán, El gringo de confianza, Memorias de un médico alemán en Montevideo entre el fin de la Guerra del Paraguay y el Civilismo, 1867-1892 (Montevideo: [s.n.], 1992), 232-234.

47 Teresita Winter, Los alemanes en el Uruguay (Montevideo: Facultad de Humanidades y Ciencias, Universidad de la República, 1979), 14.

48 El vínculo fue confirmado tanto por Ricardo Araújo (heredero de la familia Araújo) como por Leticia Chifflet (heredera de Ingeborg Bayerthal), en entrevistas mantenidas con la autora durante 2019.

49 Werner Röder y Herbert A. Strauss, International Biographical Dictionary of Central European Emigrés 1933-1945 (New York: De Gruyter, 1999), 64.

50 Anécdota provista por Ricardo Araújo en una entrevista personal con la autora. 
femenino de características modernistas, con superficies pulidas y líneas simples que le otorgan al cuerpo una sensación de tensión y tersura.

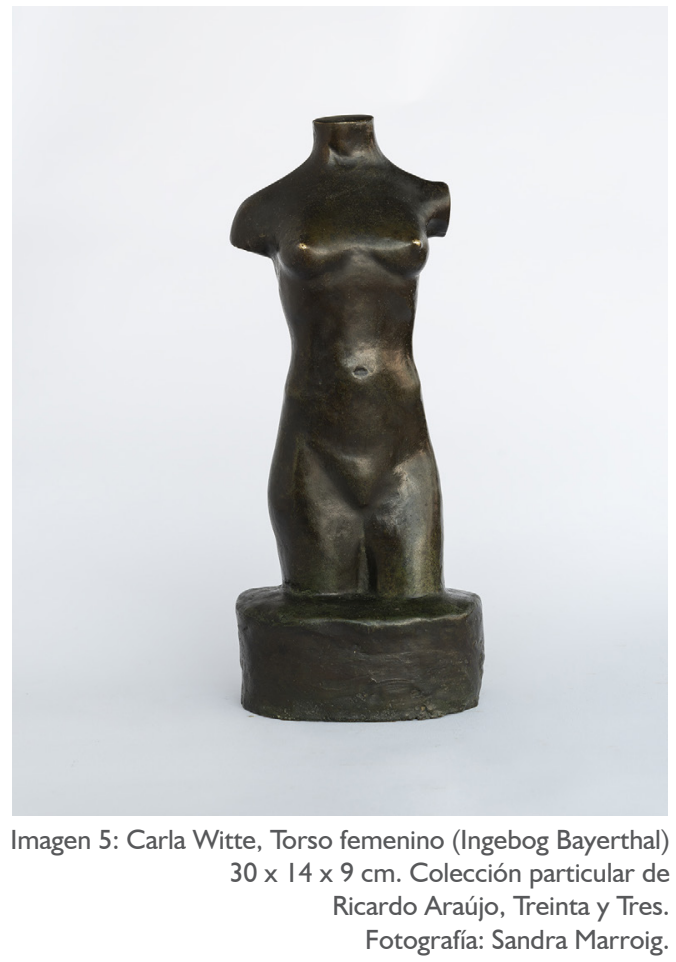

Carla Witte tuvo, además, importantes lazos con el círculo artístico local. El pintor Domingo Luis Bazurro, por ejemplo, fue testigo en su tramitación de la ciudadanía uruguaya, que obtuvo el 9 de noviembre de 1932. En ese momento, Bazurro era Director del Círculo de Bellas Artes y una reconocida figura del arte nacional. El segundo testigo fue Pedro Catelli, de la casa de arte «Moretti, Catelli y Mazzuchelli», donde se organizaban exposiciones temporarias de maestros y artistas locales como Pedro Figari, José Cúneo y Carmelo de Arzadun. Al igual que Bazzurro, Catelli tenía entonces una presencia activa en el circuito cultural y en las actividades de la Comisión Nacional de Bellas Artes.

Sin embargo, el contacto local de mayor trascendencia en la vida de Carla Witte en Uruguay fue Álvaro Araújo, quien fuera su gran amigo y mecenas. Heredero de una importante fortuna, Álvaro Araújo fue autor y traductor de numerosos artículos de la revista «La Pluma» y un gran apoyo moral y 
financiero para un numeroso grupo de artistas uruguayos que procuraban vivir de su arte. ${ }^{51}$ Además de convocarla para participar como ilustradora en «La Pluma», Araújo apoyó a Witte con críticas como la que realizó en la revista Anales en marzo de 1938. ${ }^{52}$ Bajo el título «Ante la obra de Carla Witte», esta nota presenta una fotografía en primer plano de la artista junto a sus esculturas «Virgen ${ }^{53}$, «Secreto» ${ }^{54} \mathrm{y}$ «La voz» [Imagen 8]. El texto culmina diciendo: «la obra de arte ha ayudado por un instante fugaz, a gustar la belleza de la vida y a vislumbrar el ideal de purificación colectiva de la humanidad. ¡Labor de artista! ¡Labor digna de dioses!». ${ }^{55}$

También existen testimonios sobre el vínculo que existía entre Carla Witte y la poetisa y escritora Esther de Cáceres, cuyo hogar fue centro de reunión de reconocidos intelectuales, escritores, poetas y artistas de la época. ${ }^{56}$ En este sentido, es posible sostener que Witte participó de alguna manera en este círculo de la cultura y el arte local, al menos como para realizar el retrato de figuras como Joaquín Torres García [Imagen 6] u otros que podrían asignarse a Susana Soca, Felisberto Hernández, Paulina Medeiros o la misma Esther de Cáceres. Los testimonios indican, además, que ellas se juntaban todos los martes para leer los Evangelios, que luego discutían con los demás presentes, en una actitud que ayuda a explicar la fuerte presencia mística o religiosa de parte de su obra.

En particular, existe una llamativa repetición de dibujos y pasteles con motivos religiosos en las obras que integran la colección del Museo Agustín Araújo, como los trabajos que representan escenas bíblicas tales como la escalera de Job (Génesis, 28:10) [Imagen 7], Yael matando a Sísara (Jueces, 4:21) o lo que podría ser el pasaje del levita y su concubina (Jueces, 19:21). Estas obras se caracterizan por su fuerte grafismo y tenor apocalíptico, similar al que adquirieron muchos expresionistas europeos como consecuencia de los impactos de guerra. En este sentido, al igual que con la representación del paisaje paraguayo, Witte mantiene una mirada extranjera, más preocupada por comprender el horror de los acontecimientos en términos espirituales

\footnotetext{
51 Ricardo Araújo (hermano de Carol, hijo de Álvaro Alberto, nieto de Álvaro Antonio y bisnieto de Agustín Araújo), en entrevista con la autora, septiembre, 2019.

52 Álvaro Araújo, «Ante la obra de Carla Witte», La Pluma (Año XVIII, N¹8): 49.

53 Se desconocen los detalles y la ubicación de esta obra

54 Carla Witte, Silencio, c. 1938, madera, 43 x 10 × 33 cm. Colección particular de la familia Araújo.

55 Existen otras menciones a su obra, como es el caso de la reproducción de su pintura «Pueblo de Monserrat» en la Sección de Arte Nacional "La Pluma» del mes de febrero de 1929 (Año 3, V. 10, p. 46).

56 Marta Behrens de Cáceres, «Esther de Cáceres (1903-1971) - una semblanza», entrevista por Antonio Turnes, 5 de mayo, 2006.
} 
que por retratar la temática religiosa con relación a problemáticas específicas de carácter local, tales como el sincretismo religioso y los procesos de secularización de la cultura. ${ }^{57}$

Witte también ilustró libros como «Peregrinaciones de mi Espíritu» del obispo metodista Sante Uberto Barbieri, editado en colaboración con la Comisión de Literatura Cristiana del Comité de Cooperación en América Latina y publicado por Librería «La Aurora», Buenos Aires, en 1942. Y algunos de sus trabajos fueron publicados en la revista «Devenir», del capítulo uruguayo de la Sociedad Teosófica. ${ }^{58}$ Sin embargo, se trata de ediciones póstumas que posiblemente fueron autorizadas por el mismo Álvaro A. Araújo o por su padre, Agustín Araújo, quienes participaban de esta agrupación ${ }^{59}$ junto con otros reconocidos personajes de la época, como el artista plástico Mario Radaelli (fundador de la Sociedad Teosófica del Uruguay), el poeta Carlos Sabat Ercasty y el pianista Eduardo Dieste - también asiduos concurrentes de las tertulias de Esther de Cáceres.

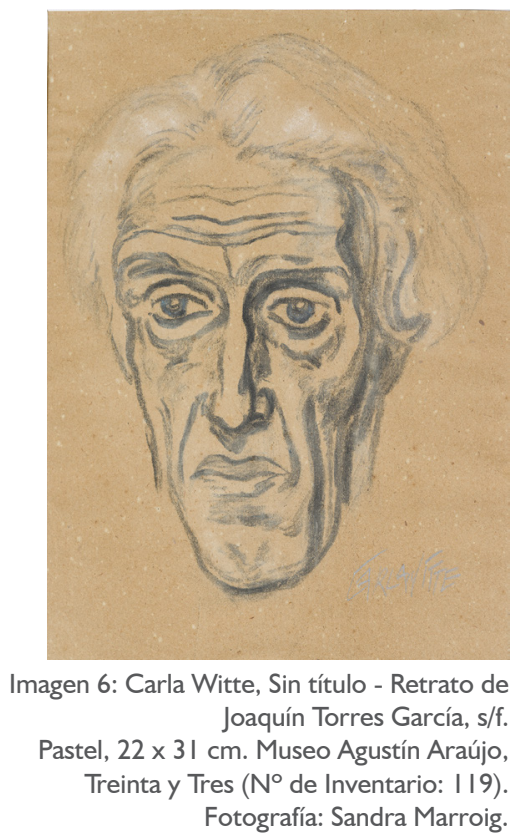

57 María Frick, «Expressionism in Latin America and Its Contribution to the Modernist Discourse», The Routledge Companion to Expressionism in a Transnational Context (2018): 521.

58 Específicamente, en las portadas de los números VI (marzo de 1946), VII (julio de 1946, que incluye una ilustración en la primera página) y XIII (diciembre de 1947).

59 Datos confirmados por Carol Araújo (hermana de Ricardo Araújo y nieta de Álvaro Antonio Araújo) en entrevista con la autora en septiembre de 2019 


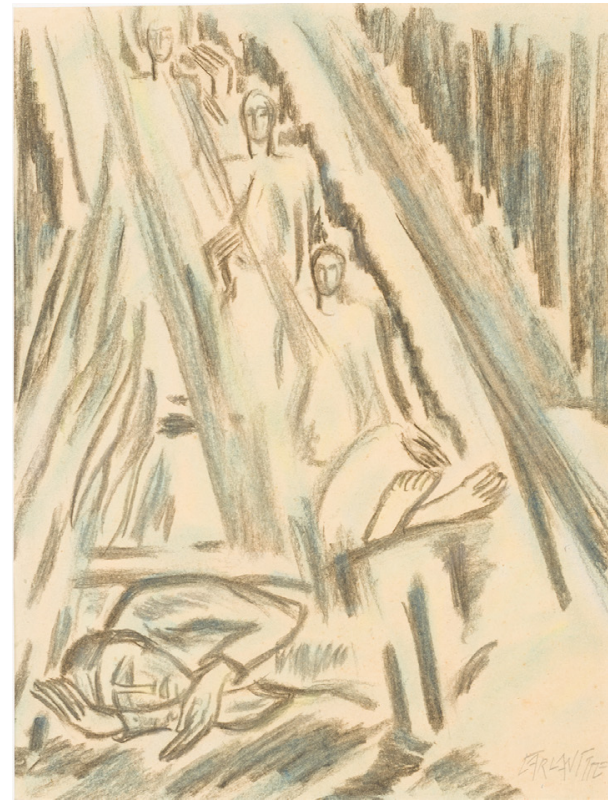

Imagen 7: Carla Witte, Sin título (Escalera de Job), s/f. Pastel, $26 \times 35 \mathrm{~cm}$. Museo Agustín Araújo, Treinta y Tres ( $\mathrm{N}^{\circ}$ de inventario: I I 2). Fotografía: Micaela Fernández.

\section{Participaciones en la cultura local}

A pesar de las escasas instituciones y salas de exposición de la época, Carla Witte tuvo una participación relativamente activa en el circuito artístico local. Ella vendió su trabajo en la «Casa Moretti, Catelli y Mazzuchelli», realizó propuestas gráficas para distintas instituciones y empresas, entre las que se encuentran la Alianza Uruguay - Estados Unidos o radio Carve. Ella también participó en exposiciones, como la que tuvo lugar en la Sala de Arte «La Giralda» ${ }^{60}$ o la que fue organizada en su propio estudio en el mes de diciembre de $1928 .{ }^{61}$

Witte también participó en eventos como el Salón de Primavera de 1932, organizado por el Círculo de Bellas Artes, ${ }^{62}$ y su obra fue aceptada en los

\footnotetext{
60 Noticia titulada «Salón La Giralda», La Pluma, Año 2, v. 8, (Set. 1928): 157.

61 Noticia titulada«Salón La Giralda», La Pluma, Año 2, v. 8, (Set. 1928): 157.

62 Datos que surgen del trámite de ciudadanía de Carla Witte.
} 
Salones Nacionales organizados por la Comisión Nacional de Bellas Artes del Ministerio de Instrucción Pública. En el 2do Salón Nacional de 1938, por ejemplo, ella presentó los dibujos: «Crepúsculo» y «Los rayos» y las esculturas: «La voz» (en madera) [Imagen 8] y «De profundis» (bronce), mientras que en las siguientes ediciones participó únicamente con obras escultóricas: «Sonámbula» (1939, yeso patinado), «Danzarina» (1940, lacre), «Reflejo» (1941, yeso pintado), y «Dormir y despertarse» $\left(1942\right.$, madera) ${ }^{63}$

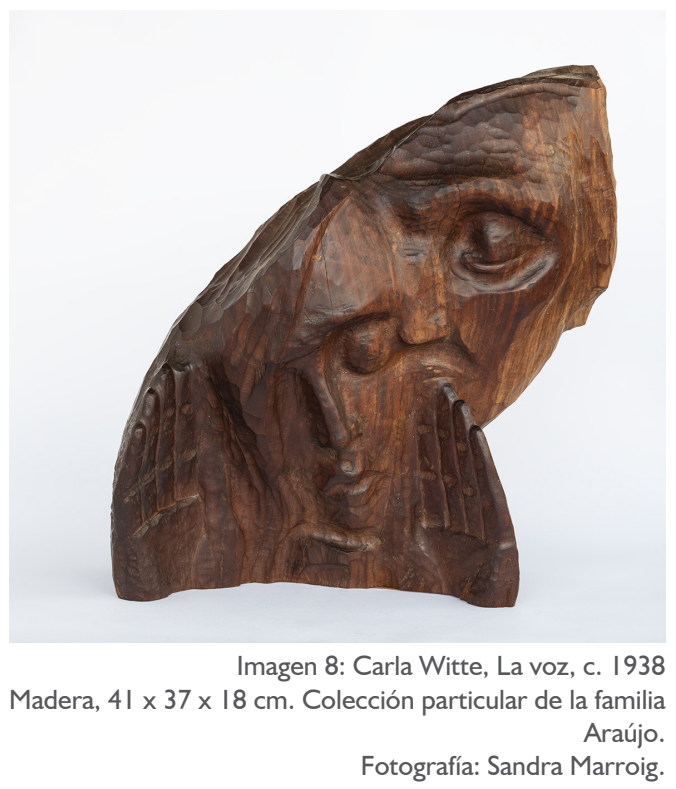

«La voz»y «Dormir y despertarse», en particular, se alinean con la revalorización expresionista de la madera como material escultórico debido a su fuerte vinculación con lo artesanal y primitivo y su potencial expresivo en términos de su irregularidad, textura y color. ${ }^{64}$ Esto también se ve claramente en obras como la escultura de la Iglesia de la Congregación Evangélica Alemana, en la que Witte utiliza la madera para crear una textura casi dramática, que otorga cierto ritmo y expresión a la monumentalidad de

63 Desafortunadamente, en la medida en que no existe un registro fotográfico de las obras presentadas en los Salones Nacionales y que el catálogo de las obras de la colección del Museo Agustín Araújo no incluye información sobre todos los títulos originales, es imposible identificar estas piezas y, en consecuencia, poder analizarlas en profundidad.

64 Monika Wagner, «Wood- primitive material for the creation of German sculture», en New Perspectives on Brücke Expressionism: Bridging History, ed. Christian Weikop (Farnham, Surrey; Burlington, VT : Ashgate, 2011): 71-88. 
las manos. Por otro lado, otras de sus obras escultóricas, como «Tristeza» ${ }^{65} \mathrm{O}$ «Sin título (Cabeza) » ${ }^{66}$ se asemejan claramente con la producción de expresionistas europeos como Kate Kollwitz (Die Klage o «Lamento») o Ernst Barlach (Kopf o «Cabeza»), ya sea en términos de la expresión de las formas, en el primer caso, como de la utilización de líneas claras y volúmenes marcados en la definición de las figuras, en el segundo.

Estas características también se observan en los dibujos que realiza la artista. En particular, el gran número de desnudos que componen la colección del Museo Agustín Araújo se caracteriza por la utilización de líneas fuertes, que definen con decisión los cuerpos de las modelos, en su gran mayoría mujeres y en poses no ensayadas [Imagen 9]. Si bien los expresionistas se opusieron en general a la desnudez idealizada de las academias tradicionales, en esta serie de dibujos de Carla Witte se hace palpable una percepción de la realidad muy sensualizada, que parece oscilar entre posiciones claramente definidas (e incluso de cierta violencia latente) y otras de aparente fragilidad.

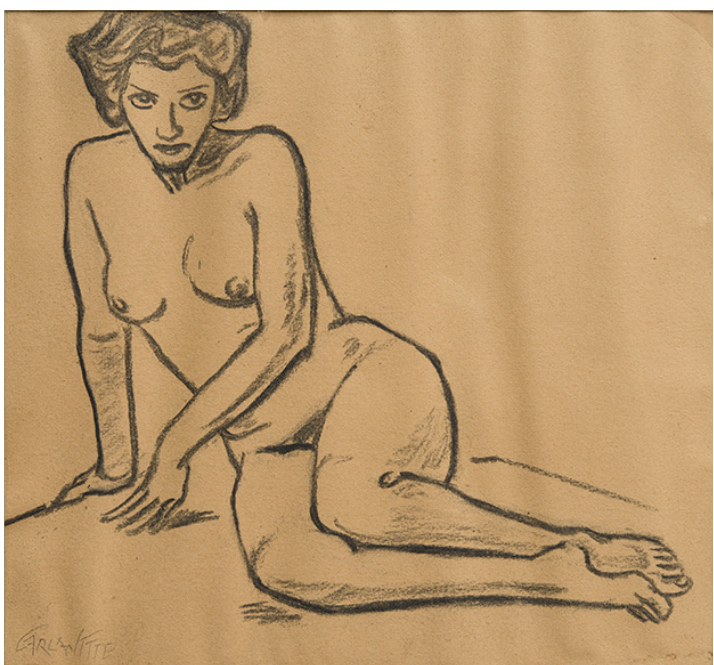

Imagen 9: Carla Witte, Sin título - Desnudo femenino, s/f. Carbonilla, $25 \times 23 \mathrm{~cm}$. Museo Agustín Araújo, Treinta y Tres ( $\mathrm{N}^{\circ}$ de inventario: 97$)$. Fotografía: Sandra Marroig. 
No obstante, la obra de Carla Witte que tuvo mayor difusión y por la que ella ha trascendido como una artista expresionista es la de tipo gráfico, especialmente las ilustraciones que realizó para «La Pluma» entre 1928 y 1931. En total, Witte realizó 15 ilustraciones en 6 ejemplares de los 19 que tuvo la revista, con 10 de ellos en la sección de Álvaro Araújo titulada «Los anónimos ritmos del dolor. Datos, historias, narraciones y comentarios de la tragedia humana en todos los países. (Escritos recopilados por Álvaro A. Araújo, e ilustrados por Carla Witte)», caracterizada por una temática casi agresiva (desesperación, sufrimiento, tortura física y espiritual) y un tono de fuerte crítica política y social, en general de izquierda y pacifista.

Las ilustraciones son: «Salomé. Temas musicales de la danza. Apunte de Carla Witte en un concierto de Kraus» (Año 2, V. 8, sept. 1928, p. 44. Autoría en título); «La Esponja. Monólogo, 2do acto Las Campanas. Drama en dos actos y un prólogo con orquesta de Olga Brendel de Rust» (Año 2, V. 8, sept. 1928, p. 46. Firmado); «Mi fuerza de Horace Traubel» (Año 3, V. 10, feb 1929, p. 104. Firmado); «La mártir, por E. Sylvia Pankhurst (de la obra “The suffragette”)» (Año 3, V. 10, feb 1929, p. 106. Sin firma, autoría en sumario); «Padre nuestro que estás en los cielos, por Wilhelm Lamszus (de la obra “The human slaughterhouse”)» (Año 3, v. 11, abr. 1929, p. 109); "La niñez desvalida, de Gabriela Mistral” (de la obra "Desolación") (Año 3, v. 11, abr. 1929, p. 111, firmada); «Arrojada de Gabriela Mistral» (de la obra «Desolación») (Año 3, v. 11, abr. 1929, p. 113, firmada); «El destino manifiesto, de J.P.Pove» (Año 3, v. 1, jun. 1929, p. 74, firmada); «El oro amasado con sangre» (Año 3, v. 12, jun. 1929, p. 76, firmada); «La venganza organizada, de Oscar Wilde» (Año 3, v. 1, jun. 1929, p. 78, firmada); «Conquistadores modernos de Nathaniel Peffer», con la leyenda «Erich-Maria Remarque». Autor del libro «Nichts Neuesim Westem. Dibujo de Carla Witte» (Año 3, v. 13, oct. 1929, p. 116, firmada); «El eternamente crucificado, de Félicité Robert de Lamennais» (de la obra «Palabras de un creyente») (Año 3, v. 16, oct. 1930, p. 121); «El concurso de bebés, de Maurice Magre» (de la obra «Por qué soy budista») (Año 4, v. 16, oct. 1930, p. 123, firmado); «Manuel Ugarte habla a la juventud. La obra continental» (firmado por Manuel Ugarte con fecha Niza, mar. 1931) (Año 5, v. 19, set. 1931, p. 6., sin firma); y «El martirio de la humanidad. El aniversario de un drama: Con firma y título «Dibujo de Carla Witte» (Año 5, v. 19, set. 1931, p. 46). 


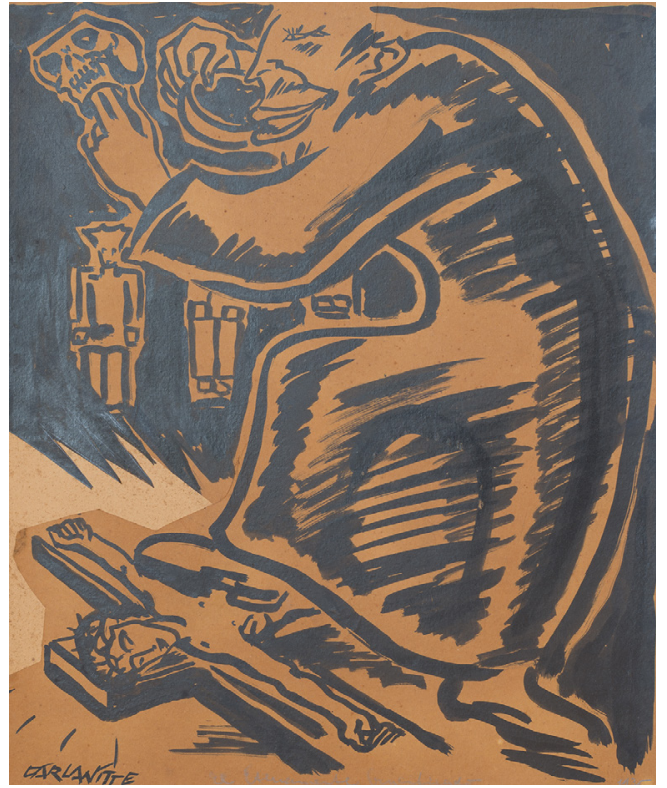

Imagen I0: Carla Witte, Sin título - Ilustración para La Pluma: "El eternamente crucificado".

Tinta, $34 \times 42 \mathrm{~cm}$. Museo Agustín Araújo, Treinta y Tres ( $\mathrm{N}^{\circ}$ de inventario: 92$)$. Fotografía: Micaela Fernández.

Más allá del vínculo personal entre Witte y Araújo, estas colaboraciones eran usuales en la época, en la que existía una estrecha interrelación entre literatos y artistas. «La Pluma», en particular, también se caracterizó por una fuerte presencia de la técnica xilográfica y del vanguardismo europeo de tendencia expresionista. ${ }^{67}$ Esto es particularmente claro en las ilustraciones y viñetas de Carla Witte, en la que se hace especialmente explícito el carácter expresionista que estaba latente en sus trabajos anteriores. «La esponja» ${ }^{68}$ «El eternamente crucificado» [Imagen 10], «Manuel Ugarte habla a la juventud» ${ }^{69}$ $\mathrm{y}$ «El martirio de la humanidad», ${ }^{70}$ por ejemplo, denotan un claro manejo de los elementos formales y las formas expresivas del expresionismo, al mismo tiempo que transmiten un estado de espíritu, una angustia casi metafísica similar a la de obras como Die Eltern (Los padres) de Kathe Köllwitz, Elias in

67 Gerardo Mantero, «Entrevista a Rodrigo Gutiérrez Viñuales: Libros argentinos, ilustración y modernidad (1910-1936) », La Pupila, n 36 (2015): 4.

68 Carla Witte, "Sin título - Ilustración para La Pluma: «La Esponja», tinta, 24 x 28 cm. Museo Agustín Araújo, Treinta y Tres ( $\mathrm{N}^{\circ}$ de inventario: 93$)$.

69 Se desconocen los detalles y la ubicación de esta obra.

70 Se desconocen los detalles y la ubicación de esta obra. 
der Wüste (Elías en el desierto) de Christian Rohlfs, Arbeiter. Hunger. Todnaht (Trabajadores. Hambre. La muerte se acerca) de Heinz Fuchs (1919) o An alle Künstler (¡A todos los artistas!) de Max Pechstein.

Otra obra que se destaca es «La venganza organizada» ${ }^{71}$, tanto por su color como por su cruda representación de la muerte y, con ella, de la naturaleza humana. Acompañando un extracto de Ballad of Reading Gaol (Balada de la Cárcel de Reading), la obra representa el relato de Oscar Wilde sobre el ahorcamiento del soldado Charles Thomas Wooldridge, acusado de haber degollado a su esposa. La misma presenta características muy similares a grabados expresionistas como, por ejemplo, Leuchtbake (Faro) y Angler (Pescadores) de Lyonel Feininger, en las que el artista utiliza fuertes contrastes para perfilar las formas de las máquinas y los hombres que componen el paisaje; pero tanto en su utilización del color como de las diagonales la obra también incorpora una tensión similar a la de los paisajes apocalípticos de Ludwig Meidner.

Un carácter similar, aunque más moderado, se ve en las ilustraciones que Witte realizó para «Anales Revista Nacional». Ejemplo de ello son: las carátulas de los números 116 (Año XVII, diciembre de 1937. Firmado) ${ }^{72}, 117$ (Año XVIII, febrero de 1938. Firmado) ${ }^{73}$ y 118 (Año XVIII, marzo de 1938. Sin firma $)^{74}$ y los dibujos que acompañaban los artículos «Teatro japonés por Gonzalo Aritza Vélez» (Año XVIII - N 117, febrero de 1938, p. 27 y 28. Sin firma) ${ }^{75}$, «Caso de conciencia» de María Morrison de Parker (Año XVIII - N ${ }^{\circ}$ 117, febrero de 1938, p. 46. Firmado) [Imagen 11] y «Dionea gigantea» de Otto Miguel Cione (Año XVIII - No 118, marzo de 1938, p. 51-52. Firmado). ${ }^{76}$

71 Carla Witte, Sin título - Ilustración para La Pluma: «La venganza organizada», tinta 32 x 35 cm. Museo Agustín Araújo, Treinta y Tres ( $\mathrm{N}^{\circ}$ de inventario: 86).

72 Se desconocen los detalles y la ubicación de esta obra.

73 Se desconocen los detalles y la ubicación de esta obra.

74 Se desconocen los detalles y la ubicación de esta obra.

75 Se desconocen los detalles y la ubicación de esta obra.

76 Se desconocen los detalles y la ubicación de esta obra. 


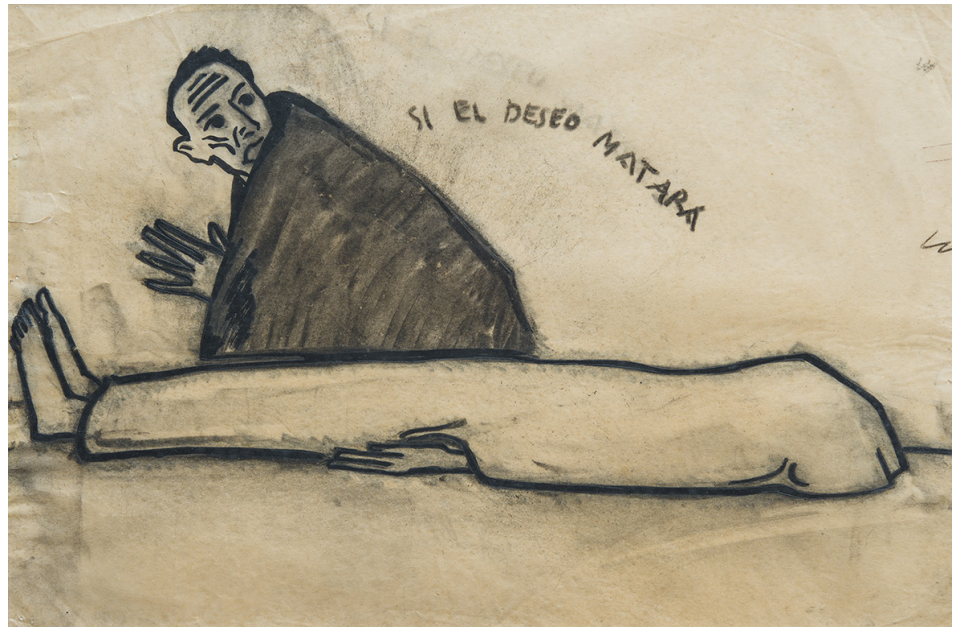

Imagen I I: Carla Witte, Sin título - Ilustración para Anales: "Caso de conciencia» de María Morrison de Parker, s/f.

Tinta, sin medida. Museo Agustín Araújo, Treinta y Tres ( $\mathrm{N}^{\circ}$ de inventario: 840 ). Fotografía: Sandra Marroig.

\section{Hipótesis sobre una muerte trágica}

La vida de Carla Witte en Uruguay termina de manera tan enigmática como empieza: el 8 de mayo de 1943, con cincuenta y cuatro años de edad, se suicidó de un balazo en la sien en un bosque de pinos del actual barrio de Carrasco. ${ }^{77} \mathrm{Y}$ aunque otra vez se desconocen los motivos que la llevaron a esta decisión, debe considerarse que en esa época el suicidio no solo tenía un fuerte atractivo emocional ${ }^{78}$ y era visto como una «señal de los tiempos» ${ }^{79}$ sino que, para muchos escritores y emigrados significaba la posibilidad de un escape real del caos, la pobreza y la depresión. Tal es el caso del escritor vienés

\footnotetext{
77 Datos que surgen de la partida de defunción Serie A N. 4300352, caratulada como suicidio, y de la información provista por Mariví Ugolino a partir de la transcripción de la microfilmación del parte policial. De estas fuentes se puede reconstruir que el cuerpo de Carla Witte fue encontrado a primera hora de la tarde en el cruce de las calles General Nariño y Daymán (hoy Av. Rivera) y luego velado en la casa funeraria Miramonte (actualmente inexistente), cita en la calle Dante (hoy Eduardo Víctor Haedo) 2169. El 10 de mayo, Witte fue enterrada en el Cementerio Británico (Sepulcro N. 15), en una tumba comprada por Álvaro Araújo y que hasta el día de hoy permanece sin lápida.

78 Anne Nesbet, «Suicide as Literary Fact in the 1920s». Slavic Review, n 4 (1991): 828.

79 Moritz Föllmer, «Suicide and Crisis in Weimar Berlin», Central European History, n 42 (2009): 209.
} 
Stefan Zweig, cuya carta de despedida puede ser especialmente esclarecedora con respecto a los motivos que pudieron pesar en la decisión de Carla Witte:

Declaración por mi propia voluntad y en plena lucidez. Cada día he aprendido a amar más este país, y no habría reconstruido mi vida en ningún otro lugar después de que el mundo de mi propia lengua se hundiese y se perdiese para mí, y mi patria espiritual, Europa, se destruyese a sí misma. Pero comenzar todo de nuevo cuando uno ha cumplido sesenta años requiere fuerzas especiales, y mi propia fuerza se ha gastado al cabo de años de andanzas sin hogar. Prefiero, pues, poner fin a mi vida en el momento apropiado, erguido, como un hombre cuyo trabajo cultural siempre ha sido su felicidad más pura y su libertad personal, su más preciada posesión en esta tierra. Mando saludos a todos mis amigos. Ojalá vivan para ver el amanecer tras esta larga noche. Yo, que soy muy impaciente, me voy antes que ellos. Stefan Zweig, Petrópolis, 22/2/1942. ${ }^{80}$

En esos años, el país atravesaba una fase de grave deterioro social, político y económico que hacía que la vida cotidiana del inmigrante fuera especialmente difícil, sobre todo para aquellos que arribaron después de la Primera Guerra Mundial carentes de medios económicos propios. ${ }^{81} \mathrm{La}$ «ley de inmigración indeseable» $(1932)^{82}$, además, había promovido el surgimiento de «fuertes señales de xenofobia y hasta de racismo» ${ }^{83}$, que para los miembros de la colectividad alemana empeoraron notoriamente cuando los avances de Hitler en Europa dieron lugar a la percepción de la amenaza de una «infiltración nazi». ${ }^{84}$

En 1939, la Batalla del Río de la Plata y la recalada del Admiral Graf Spee en el puerto de Montevideo generaron «la convicción de que la guerra, tangible, física, podía llegar hasta aquí ${ }^{85}$, temores que fueron luego reafirmados con la publicación de «Nazis en el Uruguay» de Hugo Fernández Artucio ${ }^{86}$ y la creación de una Comisión Investigadora de Actividades Antinacionales, que

80 Stefan Zweig, Carta original, junio de 1942. Israel: Depósito de la Memoria, Biblioteca Nacional, 1942.

81 María M. Camou, «El nacional-socialismo en Uruguay, 1933-1938», Cuadernos del CLAEH, n 38 (1986): 69.

82 Silvia Facal, «Política inmigratoria de puertas cerradas. Uruguay frente a la llegada de refugiados españoles republicanos y judíos alemanes», Revista Complutense de Historia de América 28, (2002): 173.

83 Gerardo Caetano y Milita Alfaro, Historia del Uruguay Contemporáneo: materiales para el debate (Montevideo: Fundación de Cultura Universitaria, 1995), 162.

84 Carolina Cerrano y Fernando López, «Las Fuerzas Armadas uruguayas durante la Segunda Guerra y el advenimiento del peronismo (1939-1945)», Historia 1 (2018).

85 Carlos Real de Azúa, «Política Internacional e Ideologías en el Uruguay», $M A R C H A, \mathrm{n}^{\circ} 966$ (1959).

86 Hugo Fernández Artucio, Nazis en Uruguay (Montevideo: Talleres Gráficos Sur, 1940) 
identificó una organización nacional-socialista local que procuraba anexar el país al Tercer Reich. Como consecuencia, en 1940 el gobierno promulgó una ley de instrucción militar obligatoria que — si bien nunca se cumplióprovocó que contingentes de ciudadanos se alistaran como reclutas ${ }^{87}$, se creara un cuerpo de enfermeras voluntarias ${ }^{88}$ y se establecieran polígonos para prácticas de tiro con fusil de guerra en todo el país ${ }^{89}$.Uruguay también accedió a las políticas aliadas de boicot mediante la creación de «listas negras» que discriminaban a los súbditos del Eje y a sus simpatizantes (o sospechosos de serlo), provocando que muchas empresas e instituciones alemanas cerraran y que numerosos profesionales y empleados vinculados a la colectividad perdieran sus ingresos y fuentes de trabajo. ${ }^{90}$

Tal era la percepción de la posibilidad de la guerra que en 1942 también se organizaron ensayos de oscurecimiento y bombardeos, llegándose a emitir un decreto que establecía la responsabilidad del Estado en «salvaguardar en lo posible y custodiar la vida y los bienes de los habitantes de los centros poblados de la República, que se vieren atacados por medios aéreos, químicos o bacteriológicos». Esta medida llegó a imponer que los habitantes debían cooperar en dicha tarea, lo que llevó a la creación grupos de «defensa pasiva», agrupados por manzanas en los barrios de Montevideo, para denunciar a los sospechosos de actividades pro-nazis. ${ }^{91}$ En este sentido, puede suponerse que Carla Witte vivió momentos especialmente difíciles, tanto desde el punto de vista económico como social, más aun considerando que el conflicto atravesó también al colectivo de inmigrantes, que estaba fuertemente dividido entre los simpatizantes del Tercer Reich y los militantes de movimientos antifascistas o antinazis, tales como el Comité Alemán Antifascista de Montevideo o el movimiento internacional Alemania Libre.

Por otro lado, en el caso de Carla Witte [Imagen 12] también pueden considerarse motivaciones vinculadas a la «defensa de una subjetividad legítima» en un contexto en el que un gran número de jóvenes, artistas, homosexuales y «nuevas mujeres» que luchaban por una vida de alguna manera

87 El País, «Vitrinas al horror de la guerra», El País (Uruguay), 3 de octubre, 2015, Información, https://www. elpais.com.uy/informacion/vitrinas-horror-guerra.html\#

88 Ramón Rojas, Historia del Gremialismo Médico en el Uruguay (Montevideo: Sindicato Médico del Uruguay, 1990), 67.

89 Cerrano y López, «Las Fuerzas Armadas uruguayas...».

90 Carlos Real de Azúa, «Política Internacional e Ideologías en el Uruguay», MARCHA, no 966 (1959),

91 Richard Cardozo, «La "Batalla del Río de la Plata”: participación del Ministerio de Defensa, particularmente el Ejército Nacional en las derivaciones del hecho» (tesis de grado, Instituto Militar de Estudios Superiores del Uruguay, 2008), 28. 
diferente y más sustancial que las normas e instituciones vigentes permitidas. ${ }^{92}$ Las «nuevas mujeres», ${ }^{93}$ en particular, surgieron después de la Primera Guerra Mundial en estrecha vinculación con los cambios en los estilos de vida y la moda femenina: llevaban el Bubiköpfe (pelo corto), faldas más cortas, tops y suéteres lisos, ropa deportiva y a veces, incluso, accesorios decididamente masculinos; existían, además, en todas las clases y segmentos de la sociedad, eran económicamente autónomas y tenían una actitud autoconsciente hacia la sexualidad.

Existen testimonios de que Carla Witte era una mujer independiente, con una personalidad fuerte y definiciones personales no convencionales, pero en Uruguay todavía existía un pensamiento conservador muy fuerte ${ }^{94}$ que impedía que las mujeres participaran plenamente de los circuitos artísticos locales o las tertulias intelectuales de los cafés. Muchas de ellas, además, preferían afiliarse a actitudes o escuelas artísticas menos extravagantes, utilizaban sus nombres de casadas ${ }^{95}$ y, en algunos casos, llegaban a oponerse al voto femenino. ${ }^{96}$

Finalmente, en otro nivel de acontecimientos, tampoco puede dejar de considerarse la posibilidad de que la certeza de la derrota de Alemania haya sido un desencadenante, no tanto como una forma de salvar el honor (como sucedía en el caso de los líderes nazis ${ }^{97}$ sino como un acto de desesperación ante la certeza de la catástrofe y el fin de la propia patria. ${ }^{98}$ En este sentido, puede pensarse en la posibilidad de que la ola de suicidios que tuvo lugar en Alemania durante las semanas previas a la rendición ${ }^{99}$ ocurriera más

92 Moritz Föllmer, "Suicide and ...”, 221.

93 Rüdiger Graf, «Anticipating the Future in the Present: "New Women" and Other Beings of the Future in Weimar Germany», Central European History 42, n 4 (2009): 663.

94 Si bien el país fue el primero de la región en aprobar la ley de divorcio, en 1907, y el sufragio femenino, en 1932, no fue hasta 1946 que se aprobó la Ley de Derechos Civiles de la Mujer (Ley 10.783) que permite a la mujer administrar sus bienes, comprar y vender por sí, compartir la administración y división de la sociedad conyugal y el ejercicio de la patria potestad de sus hijos menores de edad, aunque se divorcie y se case con otro hombre. En Alemania, por otra parte, el voto femenino había sido aprobado en 1919 y desde ese mismo año existía la igualdad en la educación para los sexos, la igualdad de oportunidades en los nombramientos del servicio civil y la igualdad salarial en las profesiones

95 Entre ellas: Juana de Ibarbourou, Esther de Cáceres, Sara de Ibáñez o María V. de Muller.

96 Silvia Rodríguez, «El papel de la mujer en una sociedad de cambios» (1916-1932), Los veinte: el proyecto uruguayo. Arte y diseño de un imaginario 1916-1934 (1999): 120.

97 Por falta de evidencias se ha descartado la posibilidad de que Carla Witte fuera nazi o simpatizara de alguna manera con el nazismo. No obstante, no puede menospreciarse la posibilidad de que tuviera posicionamientos políticos definidos o que incluso participara en alguna organización local o internacional.

98 En Uruguay, la ola de suicidios tuvo algunos seguidores dentro de la comunidad alemana ya que -según testigos de la época- en esos años un grupo de inmigrantes radicados en Montevideo había tomado la decisión de suicidarse (Leticia Chifflet (heredera de Ingeborg Bayerthal), en entrevista con el autor, junio, 2019).

99 Christian Goeschel, «Suicide at the End of the Third Reich», Journal of Contemporary History 41, $\mathrm{n}^{\circ} 1$ (2006): 157. 
tempranamente en lugares como Uruguay, donde la prensa siempre mostró el horror de los acontecimientos y, partir de 1943, el comienzo de la derrota del Eje.

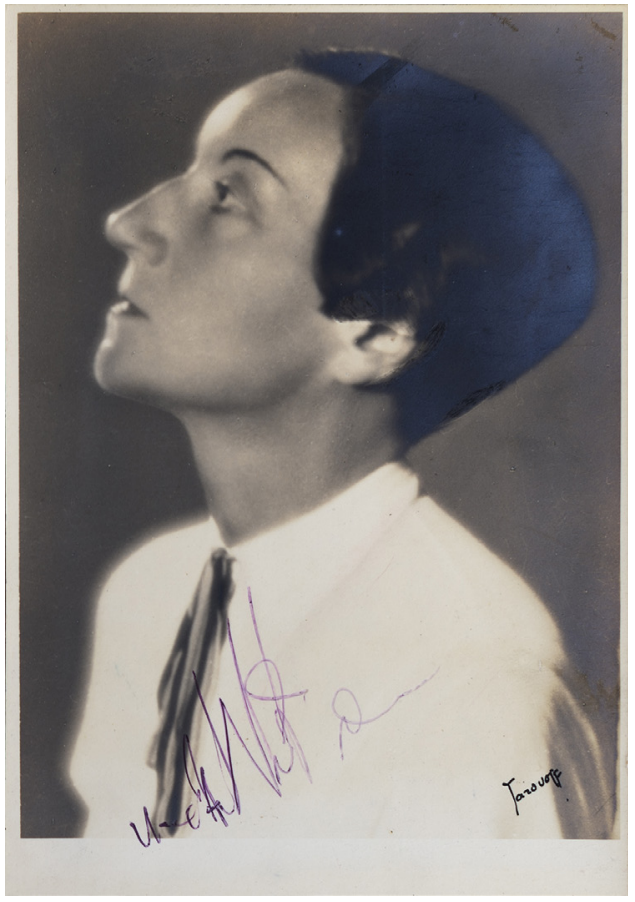

Imagen 12: Fotografía de Carla Witte (perfil), autor desconocido, c. 1938, Archivo del Museo Agustín Araújo. Fotografía: Micaela Fernández.

\section{Comentarios finales}

Más allá del misterio que puede envolver cualquier vida de la que poco se sabe, la información que existe hasta el momento indica que Carla Witte era una representante de sus tiempos. Ella parece haber sido una artista con talento y una mujer determinada que emigró escapando de una Europa en destrucción y que vivió sus últimos días en un lugar que terminó siendo hostil. Una inmigrante sola, en un país lejano y distinto a ella, desde el que podía ver la muerte final de su patria y, posiblemente, de sus seres queridos. Una extranjera sin familia, refugiada en los frágiles vínculos de las diásporas, 
a la merced de la amabilidad de la sociedad local y de las posibilidades del magro mercado de acogida.

Ante la ausencia de datos concretos es imposible identificar si Carla Witte formó a artistas locales que hayan continuado con su legado. No obstante, esto parece poco importante frente a la cantidad de obras que la familia de su amigo y mecenas, Álvaro Antonio Araújo, donó a la ciudad de Treinta y Tres. Esta colección supone una posibilidad única para abordar las redes expresionistas en todo su alcance, tanto en términos plásticos, como geográficos y humanos. Es decir, que permite seguir los rastros de una tendencia artística que, más allá de cualquier categorización, supo trascender las distintas etapas de los artistas, llegando a las fronteras más remotas con un discurso humano siempre igual de claro y trascendente.

Este legado no sólo demanda un lugar propio en el relato del arte nacional, sino que abre nuevos interrogantes que atender. En primer lugar, la vida de Carla Witte demuestra la importancia de estudiar algunos casos que, aunque minoritarios y esquivos, han tenido profundas consecuencias para el país, como es el caso de las revistas de vanguardia. Porque si bien las pinturas y esculturas no alcanzaron un amplio nivel de difusión, sus dibujos han impregnado las ilustraciones de estas publicaciones de enorme alcance y permanencia a nivel nacional. Este tipo de análisis podría integrarse, además, en un relevamiento de mayor profundidad sobre el arte gráfico local.

En segundo lugar, la reconstrucción de la trayectoria de Carla Witte es un claro testimonio del alcance del expresionismo en la cultura local. Aunque no tuvo un lugar preponderante, las ideas y principios plásticos expresionistas se difundieron de la mano de los inmigrantes que arribaron al país, la circulación de publicaciones nacionales y extranjeras y los viajes de estudio y formación que realizaban los artistas locales a Europa. De esta manera, fue posible que muchos actores locales se volvieran socios activos de este movimiento, reelaborando sus ideas y modalidades expresivas en la producción de un arte propio en el marco del debate local sobre la modernidad

A pesar de ello, debe subrayarse que el abordaje de Carla Witte -aún en sus distintas etapas- no deja de ser extranjero. Esto se manifiesta tanto en los paisajes paraguayos como en las escenas místico-religiosas realizadas en Uruguay. Los paisajes, rebosantes de color y calor, no dejan de ser representaciones de un mundo recién descubierto, mientras que las escenas bíblicas son representaciones de un drama universal que no está necesariamente vinculado a la región. El dolor, la denuncia y la angustia 
expresionista de Carla Witte no parecen estar vinculados a Uruguay sino trascender los límites geográficos, quizás atados todavía al devenir europeo.

Finalmente, la trayectoria de Carla Witte obliga a reflexionar sobre los discursos tradicionales sobre el arte nacional. Si ella estuvo de alguna medida tan vinculada al circuito artístico local, ¿por qué no ha sido todavía objeto de estudio? Más aún, ¿por qué hemos omitido de nuestra historiografía una posible influencia expresionista en el arte uruguayo? ¿Qué es lo que nos incomoda y nos lleva a preferir olvidar a estos personajes?

\section{Bibliografía}

Adam, Thomas. Germany and the Americas: culture, politics and history. A multidisciplinary enciclopedia. Vol. I. California: ABC Clio California, 2005.

Araújo, Álvaro. "Ante la obra de Carla Witte”, La Pluma (Año XVIII, N¹8). Behrens de Cáceres, Marta. "Esther de Cáceres (1903-1971) - una semblanza". Entrevista por Antonio Turnes, 5 de mayo, 2006. https:/ /www.smu. org.uy/dpmc/hmed/historia/articulos/esther_de_caceres1903\%20 1971.pdf

Caetano, Gerardo y Alfaro, Milita. Historia del Uruguay Contemporáneo: materiales para el debate. Montevideo: Fundación de Cultura Universitaria, 1995.

Camou, María. "El nacional-socialismo en Uruguay, 1933-1938”. Cuadernos del CLAEH, no 38 (1986): 67-83.

Cardozo, Richard. "La "Batalla del Río de la Plata": participación del Ministerio de Defensa, particularmente el Ejército Nacional en las derivaciones del hecho". Tesis de grado, Instituto Militar de Estudios Superiores del Uruguay, 2008.

Cerrano, Carolina y López, Fernando. "Las Fuerzas Armadas uruguayas durante la Segunda Guerra y el advenimiento del peronismo (1939-1945)". Historia (Santiago) 51, no1 (2018). http://dx.doi.org/10.4067/s071771942018000100011

Chapman, Kathleen. Expressionism and poster design in Germany 1905-1922: between spirit and commerce. Leiden, Boston: Brill, 2019. 
El País, "Vitrinas al horror de la guerra". El País (Uruguay), 3 de octubre, 2015, Información. https://www.elpais.com.uy/informacion/vitrinashorror-guerra.html\#

Facal, Silvia. "Política inmigratoria de puertas cerradas. Uruguay frente a la llegada de refugiados españoles republicanos y judíos alemanes". Revista Complutense de Historia de América 28 (2002): 169-183.

Facal, Silvia. "Recorriendo el largo camino de la integración: los judíos alemanes en Uruguay". Amérique Latine Histoire et Mémoire. Les Cabiers ALHIM, no 12 (2006): 123-147. http://journals.openedition.org/al$\operatorname{him} / 1412$

Flügel, Félix. "La Colonia Agrícola de Santa Teresa: una experiencia migratoria fracasada". Revista Histórica Rochense, n² (2013). https://www. revistahistoricarochense.com.uy/category/rhr-no-2/.

Föllmer, Moritz. "Suicide and Crisis in Weimar Berlin". Central European History, no 42 (2009): 195-221.

Frick, María. "El expresionismo en la pintura latinoamericana: transferencias y trascendencia". Atrio, no 20 (2014): 128-139.

Frick, María. "Expresionismo del Sur: hacia la definición de un arte propio". ILLAPA Mana Tukukuq, no 16 (2019): 86-97.

Frick, María. "Expressionism in Latin America and Its Contribution to the Modernist Discourse". The Routledge Companionto Expressionism in a Transnational Context (2018): 507-524.

Frick, María. "Los salvajes del Sur: Inmigración y expresionismo en Uruguay en la primera mitad del siglo XX". MODOS 4, n 1 (2020): 167-187.

Giunta, Andrea y Flaherty George F. "Latin American Art History: An Historiographic Turn”, Art in Translation, no 9 (2017): 121-142.

Goeschel, Christian. "Suicide at the End of the Third Reich". Journal of Contemporary History41, no 1 (2006): 153-173.

Graf, Rüdiger. "Anticipating the Future in the Present: "New Women" and Other Beings of the Future in Weimar Germany". Central European History $42, \mathrm{n}^{\circ} 4$ (2009): 647-673.

Hobsbawn, Eric. Historia del siglo XX: 1914-1991. Barcelona: Editorial Grijalbo Mondadori, 1997. 
Mañé Garzón, Fernando y Ayestarán, Ángel. El gringo de confian₹a, Memorias de un médico alemán en Montevideo entre el fin de la Guerra del Paraguay y el Civilismo, 1867-1892. Montevideo: [s.n.], 1992.

Mañé Garzón, Fernando y Burgues Roca, Sandra. Publicaciones médicas uruguayas de los Siglos XVIII y XIX. Montevideo: Universidad de la República, 1996.

Miceli, Sergio. "Artistas "nacional-extranjeros" en la vanguardia sudamericana (Lasar Segall y Xul Solar)". Prismas Revista de historia intelectual, no 13 (2009): 173-181.

Micolis, Marisa. Une communaute allemande en Argentine: El Dorado: problemes dé intégration socio-culturelle. Quebec: Centre International de Recherches sur le bilinguisme, 1973.

Nesbet, Anne. "Suicide as Literary Fact in the 1920s". Slavic Review, n 4 (1991): 827-835.

Panella, Verónica. Mujeres artistas en las vanguardias pictóricas latinoamericanas de la primera mitad del siglo XX: una imperfecta antología. En: LARROCA, Oscar y MANTERO, Gerardo (Comp.). La pupila: los primeros seis años (207-2013). Montevideo: Artes Gráficas, 2013.

Panella, Verónica. "En construcción”: la difícil inclusión de las artistas mujeres en la Historia del Arte, La Pupila, no 17 (2011): 24-27.

Peluffo, Gabriel. Historia de la Pintura Uruguaya - Tomo 2: Representaciones de la modernidad (1930-1960). Montevideo: Banda Oriental, 1999.

Peluffo, Gabriel. Realismo social en el arte uruguayo, 1930 - 1950. Montevideo: Museo Juan Manuel Blanes, 1992.

Pereda, Raquel. Carlos Alberto Castellanos, Imaginación y realidad. Montevideo: Edición Fundación Banco de Boston, 1997.

Pérez Barreiro, Gabriel. "El diálogo transatlántico en la Abstracción Geométrica". Catálogo de la exposición "América fría: la Abstracción Geométrica en Latinoamérica (1934-1973)" (11 de febrero- 15 de mayo de 2011), Fundación Juan March, Madrid.

Peroutka, Margot. "Die Deutsche Einwanderung nach Paraguay: Vom späten 19. Jahrhundert bis ins frühe 20.” (Inmigración alemana a Paraguay desde finales del siglo XIX hasta principios del siglo XX). Tesis de maestría, Universität Wien, 2012. 
Plante, Isabel. Argentinos de París. Arte y viajes culturales durante los años sesenta, Buenos Aires: Edhasa, 2013.

Quijano, Carlos. "Dardo Regules”. Marcha (Uruguay), 9 de julio de 1948.

Real de Azúa, Carlos. "Política Internacional e Ideologías en el Uruguay". $M A R C H A, \mathrm{~N}^{\circ} 966$ (1959): 7-14.

Rocca, Pablo Thiago. Catálogo de la exposición "Arte Naïf en Uruguay”. Montevideo: Fundación Unión, 2015.

Rodríguez, Silvia. "El papel de la mujer en una sociedad de cambios" (19161932). En Los veinte: el proyecto uruguayo. Arte y diseño de un imaginario 19161934, editado por Gabriel Peluffo, 113-122. Montevideo: Museo Municipal de Bellas Artes Juan Manuel de Blanes, 1999.

Röder, Werner y Strauss, Herbert A. International Biographical Dictionary of Central European Emigrés 1933-1945. New York: De Gruyter, 1999.

Rojas, Ramón. Historia del Gremialismo Médico en el Uruguay. Montevideo: Sindicato Médico del Uruguay, 1990.

Segall, Lasar. "Enciclopedia Itaú Cultural de Arte e Cultura Brasileiras". San Pablo: Itaú Cultural, 2020. http://enciclopedia.itaucultural.org.br/pessoa8580/lasar-segall

Wagner, Monika. "Wood- primitive material for the creation of German sculture". En New Perspectives on Brücke Expressionism: Bridging History, editado por Christian Weikop, 71-88. Farnham, Surrey; Burlington, VT: Ashgate, 2011.

Winter, Teresita. Los alemanes en el Uruguay (Montevideo: Facultad de Humanidades y Ciencias, Universidad de la República, 1979).

Zweig, Stefan. Carta original, junio de 1942. Israel: Depósito de la Memoria, Biblioteca Nacional, 1942. 